\title{
Aqueous vapour substitution for hydrogen in the process of pyrolysis
}

\author{
M. Demidenko ${ }^{1}$, R. Magaril ${ }^{2}$ \& E. Magaril ${ }^{3}$ \\ "“Tobolsk-Polymer" LLC, Russia \\ ${ }^{2}$ Tyumen State Oil and Gas University, Russia \\ ${ }^{3}$ Ural Federal University, Russia
}

\begin{abstract}
In order to decrease hydrocarbons fractional pressure in the process of ethylene pyrolysis, $0.5-1.5$ kilograms of aqueous vapour is added to each kilo of feedstock. In the pyrolysis of hydrocarbon feed, a considerable part of the process' power consumption is connected with water vaporization; heating up of the diluent to $800^{\circ} \mathrm{C}$ and more with the subsequent condensation.

The aim of this work is to reduce specific energy consumption and improve selectivity to ethylene of pyrolysis process.

The same hydrocarbons fractional pressure can be created as during diluting by aqueous vapour if we use hydrogen as a diluent with its mass 9 times less.

It was found that if hydrogen is purged to the furnace inlet under different feedstock temperatures prior to the pyrolitic reaction, hydrogen will become a homogeneous catalyst for the subsequent radical-chain reactions. The depth of the reaction (according to Korzun and Magaril in Thermal processes of refining 2008) will be greater, under otherwise equal conditions, than without hydrogen.

Specific heat energy consumption for the production of ethylene, as well as for the amount of ethylene and propylene, with aqueous vapour substitution to hydrogen decreases. When replacing the vapour for a considerably smaller amount of hydrogen, the latter is involved in a radical chain process, providing greater selectivity for ethylene production, thereby increasing the yield of ethylene at $15 \%$ relative. As a result, ethylene production costs are significantly reduced.

Keywords: pyrolysis, homogeneous catalysis, process selectivity, energy cost reduction, ethylene.
\end{abstract}




\section{Introduction}

Nowadays, more than 140 million tons of ethylene is produced by pyrolysis which requires more than 400 tons of hydrocarbon feedstock. Main problems of the process are specific energy consumption and low selectivity of the target product that is ethylene. Systems approach to this problems solving is currently missing in the industry. Taking into consideration the enormous scale of ethylene production by pyrolysis, reducing specific energy consumption and increasing ethylene selectivity is very important. In this paper we consider water substitution to hydrogen in the pyrolysis of propane-butane fraction where the hydrogen to feed ratio is minimal and about 1.5 moles of hydrogen to 1 mole of feed.

\section{Reduction of specific energy consumption at substitution of water for hydrogen}

Let us compare energy consumption when feed is diluted with aqueous vapour and hydrogen. As an example we take pyrolysis of propane-butane fraction at temperature $1100 \mathrm{~K}$.

Table 1 shows the calculation results based on data [2] of the energy consumption in pyrolysis of propane-butane fraction with aqueous vapour used as diluent in an amount of $0.5 \mathrm{~kg}$ per $1 \mathrm{~kg}$ of raw material according to information on the composition of pyrolysis products [3].

Table 1: Energy consumption for pyrolysis with aqueous vapour used as diluent (per $1 \mathrm{~kg}$ of raw material).

\begin{tabular}{|c|c|c|c|c|c|c|c|}
\hline \multicolumn{4}{|c|}{$\begin{array}{l}\text { Components of the input of the } \\
\text { process, } T=300 \mathrm{~K}\end{array}$} & \multicolumn{4}{|c|}{$\begin{array}{l}\text { Components of the output of the } \\
\text { process, } \mathrm{T}=1100 \mathrm{~K}\end{array}$} \\
\hline Components & $\begin{array}{l}\mathrm{x}_{\mathrm{i}} \\
\mathrm{kg}\end{array}$ & $\begin{array}{r}\Delta \mathrm{H}_{300} \\
\mathrm{~kJ} / \mathrm{kg}\end{array}$ & $\begin{array}{c}\Delta \mathrm{H}_{300} \cdot \mathrm{x}_{\mathrm{i}} \\
\mathrm{kJ}\end{array}$ & Components & $\mathrm{x}_{\mathrm{i}}, \mathrm{kg}$ & $\begin{array}{c}\Delta \mathrm{H}_{1100}, \\
\mathrm{~kJ} / \mathrm{kg}\end{array}$ & $\begin{array}{c}\Delta \mathrm{H}_{1100} \cdot \mathrm{x}_{\mathrm{i}} \\
\mathrm{kJ}\end{array}$ \\
\hline $\begin{array}{l}\text { Pyrolysis } \\
\text { feed: }\end{array}$ & & & & $\begin{array}{l}\text { Pyrolysis } \\
\text { products: }\end{array}$ & & & \\
\hline & & & & Hydrogen & 0.01 & 16050 & 160 \\
\hline Ethane & 0.014 & 401 & 6 & Methane & 0.26 & 3475 & 904 \\
\hline & & & & Acetylene & 0.01 & 2206 & 22 \\
\hline Propane & 0.669 & 336 & 225 & Ethylene & 0.34 & 2552 & 868 \\
\hline & & & & Ethane & 0.08 & 2990 & 239 \\
\hline Butane & 0.317 & 337 & 107 & Propylene & 0.16 & 2508 & 401 \\
\hline & & & & Propane & 0.09 & 336 & 30 \\
\hline & & & & 1,3-butadiene & 0.05 & 2342 & 117 \\
\hline Subtotal: & 1 & & 338 & Subtotal: & 1 & & 2740 \\
\hline $\mathrm{H}_{2} \mathrm{O}^{*}$ & 0.5 & 1256 & 628 & $\mathrm{H}_{2} \mathrm{O}$ & 0.5 & 2235 & 1118 \\
\hline Total: & 1.5 & & 966 & Total: & 1.5 & & 3858 \\
\hline
\end{tabular}

*Liquid. 
Heat input ratio for heating of diluent is about $20 \%$ of heat input for actual pyrolysis of hydrocarbons and $17 \%$ of total energy consumption in pyrolysis. In this case, specific energy consumption per $1 \mathrm{~kg}$ of ethylene is $2892 / 0.34=$ $8506 \mathrm{~kJ} / \mathrm{kg}$.

Table 2 shows the calculation results based on data [2] of the energy consumption in the pyrolysis of propane-butane fraction with hydrogen used as diluent in an amount of $0.056 \mathrm{~kg}$ per $1 \mathrm{~kg}$ of raw material.

Table 2: $\quad$ Energy consumption for pyrolysis with hydrogen used as diluent (per $1 \mathrm{~kg}$ of raw material).

\begin{tabular}{|c|c|c|c|c|c|c|c|}
\hline \multicolumn{4}{|c|}{$\begin{array}{c}\text { Components of the input of the } \\
\text { process, } \mathrm{T}=300 \mathrm{~K}\end{array}$} & \multicolumn{4}{|c|}{$\begin{array}{l}\text { Components of the output of the } \\
\text { process, } \mathrm{T}=1100 \mathrm{~K}\end{array}$} \\
\hline Components & $\begin{array}{l}\mathrm{x}_{\mathrm{i}} \\
\mathrm{kg}\end{array}$ & $\begin{array}{l}\Delta \mathrm{H}_{300} \\
\mathrm{~kJ} \\
\mathrm{~kg}\end{array}$ & $\begin{array}{c}\Delta \mathrm{H}_{300} \mathrm{x}_{\mathrm{i}} \\
\mathrm{kJ}\end{array}$ & Components & $\mathrm{x}_{\mathrm{i}}, \mathrm{kg}$ & $\begin{array}{l}\Delta \mathrm{H}_{1100}, \\
\mathrm{~kJ} / \mathrm{kg}\end{array}$ & $\begin{array}{c}\Delta \mathrm{H}_{1100} \cdot \mathrm{x}_{\mathrm{i}}, \\
\mathrm{kJ}\end{array}$ \\
\hline $\begin{array}{l}\text { Pyrolysis } \\
\text { feed: }\end{array}$ & \multirow{3}{*}{0.014} & \multirow{3}{*}{401} & \multirow{3}{*}{6} & $\begin{array}{l}\text { Pyrolysis } \\
\text { products: }\end{array}$ & & & \\
\hline \multirow[t]{2}{*}{ Ethane } & & & & Hydrogen & 0.01 & 16050 & 160 \\
\hline & & & & Methane & 0.250 & 3475 & 904 \\
\hline \multirow[t]{2}{*}{ Propane } & \multirow[t]{2}{*}{0.669} & \multirow[t]{2}{*}{336} & \multirow[t]{2}{*}{225} & Acetylene & 0.001 & 2206 & 2 \\
\hline & & & & Ethylene & 0.390 & 2552 & 995 \\
\hline \multirow[t]{4}{*}{ Butane } & \multirow[t]{4}{*}{0.317} & \multirow[t]{4}{*}{337} & \multirow[t]{4}{*}{107} & Ethane & 0.090 & 2990 & 239 \\
\hline & & & & Propylene & 0.170 & 2508 & 426 \\
\hline & & & & Propane & 0.069 & 336 & 23 \\
\hline & & & & $\begin{array}{l}1,3- \\
\text { butadiene }\end{array}$ & 0.020 & 2342 & 47 \\
\hline Subtotal: & 1 & & 338 & Subtotal: & 1 & & 2796 \\
\hline Hydrogen & 0.056 & 4255 & 238 & & 0.056 & 16050 & 900 \\
\hline Total: & 1.056 & & 576 & & 1.056 & & 3696 \\
\hline
\end{tabular}

Heat input ratio for heating of diluent is about $27 \%$ of heat input for actual pyrolysis of hydrocarbons and there is $21 \%$ of total energy consumption in pyrolysis.

Ethylene yield increases about $15 \%$ relatively to the pyrolysis with aqueous vapor. With an insignificant increase of the overall energy consumption at $8 \%$, there is a $6 \%$ decrease in specific energy consumption per $1 \mathrm{~kg}$ of ethylene by pyrolysis with hydrogen used as a diluent, comprising $3120 / 0.39=8000 \mathrm{~kJ} / \mathrm{kg}$, it also reduces the specific energy consumption per $1 \mathrm{~kg}$ of the total yield of ethylene and propylene (Table 3 ).

Thus, by aqueous vapour substitution to hydrogen in the production of ethylene its cost is reduced by reducing the specific energy consumption. 


\section{Participation of hydrogen in radical chain reactions in the pyrolysis}

Reactions of hydrogen atoms with propane and butane molecules are not selective, i.e. reactions proceed with equal probability relative to the primary and secondary $\mathrm{C}-\mathrm{H}$ bonds.

Table 3: $\quad$ Ethylene production by pyrolysis using different diluents.

\begin{tabular}{|c|c|c|c|}
\hline Index & $\begin{array}{c}\text { Pyrolysis with } \\
\text { aqueous vapour }\end{array}$ & $\begin{array}{c}\text { Pyrolysis with } \\
\text { hydrogen }\end{array}$ & $\begin{array}{c}\text { Change, } \\
\text { relative } \\
\text { percentage }\end{array}$ \\
\hline $\begin{array}{c}\text { Total energy consumption } \\
\text { for pyrolysis, kJ } \\
\text { (per 1 kg of raw material) }\end{array}$ & 2892 & 3120 & +8 \\
\hline $\begin{array}{c}\text { Specific energy } \\
\text { consumption for ethylene } \\
\text { production, } \mathrm{kJ} / \mathrm{kg}\end{array}$ & 8506 & 8000 & -6 \\
\hline $\begin{array}{c}\text { Specific energy } \\
\text { consumption for the total } \\
\text { production of ethylene and } \\
\text { propylene, } \mathrm{kJ} / \mathrm{kg}\end{array}$ & 5784 & 5571 & -3.7 \\
\hline $\begin{array}{c}\text { Ethylene yield, } \mathrm{kg} / \mathrm{kg} \text { of } \\
\text { raw material }\end{array}$ & 0.34 & 0.39 & +15 \\
\hline $\begin{array}{c}\text { Propylene yield, } \mathrm{kg} / \mathrm{kg} \text { of } \\
\text { raw material }\end{array}$ & 0.16 & 0.17 & +6.3 \\
\hline
\end{tabular}

Thus, by reacting hydrogen atom with butane probability of primary radicals formation is $\frac{6}{10}=0.6$, and by reacting with propane is $\frac{6}{8}=0.75$. At the same reaction with a methyl radical probability of interaction for the primary bond is equal to 1 , and for the secondary are 4.5. Then the probability of the formation of primary radicals of butane is $\frac{6}{6+4.5 \cdot 4}=0.25$ and of propane is $\frac{6}{6+4.5 \cdot 2}=0.4$ (according to Korzun and Magaril [1]).

Reaction rate constants for reactions of methyl radical with hydrogen $\left(\mathrm{k}_{1}\right)$, and butane $\left(\mathrm{k}_{2}\right)$ according to $[4,5]$ are respectively:

$$
\begin{aligned}
& k_{1}=10^{12.5} e^{-\frac{42600}{R T}} ; \\
& k_{2}=10^{11.21} e^{-\frac{37600}{R T}},
\end{aligned}
$$

$\mathrm{cm}^{3}$ mole ${ }^{-1} \mathrm{c}^{-1}$. We find the ratio of the constants: 


$$
\frac{k_{1}}{k_{2}}=\frac{10^{12.5} e^{-\frac{42600}{R T}}}{10^{11.21} e^{-\frac{37600}{R T}}} \approx 10 .
$$

Then ratio of reactions rates $\mathrm{w}_{1}: \mathrm{w}_{2}$ is:

$$
\frac{w_{1}}{w_{2}}=\frac{k_{1}\left[H_{2}\right]}{k_{2}\left[C_{4} H_{10}\right]} \approx 10 \cdot 1.5=15 .
$$

Thus, we find that the rate of reaction of methyl radicals with hydrogen is 15 times greater than the rate of interaction of methyl radicals with butane at average temperature of pyrolysis $(950-1000 \mathrm{~K})$.

In view of non-precise values of the constants its ratio may be less than 10 , but the rate of reaction of the methyl radicals with hydrogen in any case substantially higher than with hydrocarbon. Since the reaction of hydrocarbons with hydrogen atom is much faster than with methyl radicals, then hydrogen exhibits the property of a homogeneous catalyst of chain propagation reactions.

Due to practically complete substitution of methyl radicals by hydrogen atoms, with the primary decomposition of hydrocarbons, the yield of ethylene is greatly increased. The resulting ethylene may be consumed in the process as a result of the reactions (5) and (6):

$$
\begin{aligned}
& \mathrm{C}_{2} \mathrm{H}_{4}+\stackrel{\bullet}{\mathrm{R}}=\mathrm{RH}+\stackrel{\bullet}{\mathrm{C}_{2}} \mathrm{H}_{3} \\
& \stackrel{\bullet}{C_{2}} H_{3}+C_{2} H_{4}\left(C_{3} H_{6}\right) \rightarrow \text { liquid products of condensation }
\end{aligned}
$$

In case of a significant concentration of hydrogen, vinyl radical reacts with hydrogen according to reaction (7), which is significantly faster than the reaction (6), this inhibits its expenditure.

$$
\stackrel{\bullet}{\mathrm{C}_{2}} \mathrm{H}_{3}+\mathrm{H}_{2}=\mathrm{C}_{2} \mathrm{H}_{4}+\stackrel{\bullet}{H}
$$

When the pyrolysis feedstock is gasoline and heavier fractions, the use of hydrogen as a diluent significantly reduces the yield of liquid products.

\section{Experimental part}

Table 4 shows data of hexane pyrolysis according to Korzun and Maragil [1] with a dilution of feedstock by inert diluent helium, and pyrolysis with hydrogen in the same ratio of diluent to the feedstock. As illustrated from the data above, the growth of ethylene selectivity under the influence of hydrogen is about $10 \%$ relative.

Hydrogen used as a diluent of the pyrolysis process can be either imported or stripped from pyrolysis products using hydrogen separation unit (in particular, 
ultra-short Pressure Swing Adsorption unit (PSA) which is the most up-to-date). Methane produced by pyrolysis may be used as a fuel for pyrolysis furnaces. Considering that the hydrogen inhibits pyrocarbon deposition in the tubes of furnaces [6] and that the replacement of aqueous vapour to hydrogen may be partial, the proposed technology seems very promising.

Table 4: Results of hexane - 1 thermal decomposition in hydrogen and helium.

\begin{tabular}{|c|c|c|c|c|c|c|c|c|}
\hline \multirow{2}{*}{ Index } & \multicolumn{8}{c|}{ Temperature, ${ }^{\circ} \mathrm{C}$} \\
\cline { 2 - 9 } & \multicolumn{2}{|c|}{550} & \multicolumn{2}{c|}{600} & \multicolumn{2}{c|}{650} & \multicolumn{2}{c|}{700} \\
\hline Diluent gas & $\mathrm{He}$ & $\mathrm{H}_{2}$ & $\mathrm{He}$ & $\mathrm{H}_{2}$ & $\mathrm{He}$ & $\mathrm{H}_{2}$ & $\mathrm{He}$ & $\mathrm{H}_{2}$ \\
\hline $\begin{array}{c}\text { Hexane } \\
\text { conversion, \% }\end{array}$ & $5.6-$ & $5.8-$ & $8.2-$ & $11.5-$ & $9.9-$ & $7.9-$ & $7.2-$ & $7.5-$ \\
\hline & 15.0 & 22.3 & 19.0 & 26.3 & 22.8 & 27.6 & 27.7 & 27.7 \\
\hline \multicolumn{1}{|c|}{ Outputs, mole/100 mole of reacted $\mathrm{C}_{6} \mathrm{H}_{12}:$} \\
\hline $\mathrm{CH}_{4}$ & 27.9 & 32.2 & 27.9 & 35.2 & 27.9 & 38.3 & 29.4 & 38.9 \\
\hline $\mathrm{C}_{2} \mathrm{H}_{6}$ & 11.9 & 15.2 & 9.3 & 15.5 & 8.1 & 14.0 & 6.8 & 12.7 \\
\hline $\mathrm{C}_{2} \mathrm{H}_{4}$ & 57.9 & 63.4 & 65.9 & 74.6 & 72.1 & 80.5 & 76.8 & 80.3 \\
\hline $\mathrm{C}_{3} \mathrm{H}_{6}$ & 68.8 & 78.6 & 68.1 & 69.0 & 63.5 & 67.7 & 58.7 & 61.8 \\
\hline $\mathrm{C}_{4} \mathrm{H}_{8}$ & 17.0 & 12.5 & 17.2 & 12.0 & 17.7 & 11.8 & 19.7 & 13.9 \\
\hline $\mathrm{C}_{4} \mathrm{H}_{6}$ & 24.7 & 21.6 & 23.6 & 21.6 & 22.8 & 20.8 & 26.3 & 20.5 \\
\hline
\end{tabular}

\section{Conclusion}

Undertaken analysis and generalization of previous studies by the authors relating pyrolysis, confirmed by the calculations presented in the paper, shows that the aqueous vapour substitution for hydrogen reduces specific energy consumption and increases the selectivity to ethylene. The obtained results allow reducing the cost of ethylene produced in the process of pyrolysis.

\section{References}

[1] Korzun, N.V., Magaril, R.Z., Thermal processes of refining, [in Russian], KDU: Moscow, 2008.

[2] Vvedenskiy, A.A., Thermodynamic calculations of petrochemical processes, [in Russian], Gostoptehizdat: Leningrad, 1960.

[3] Mukhina, T.N., Barabanov, N.L., Babash, S.E., Pyrolysis of hydrocarbons, [in Russian], Khimiya: Moscow, 1987.

[4] Kondratyev, V.N., Kinetic constants of gas-phase reactions. Reference book, [in Russian], Nauka: Moscow, 1970.

[5] Yampolskiy, Yu. P., Elementary reactions and pyrolysis production mechanism, [in Russian], Khimiya: Moscow, 1990.

[6] Magaril, R.Z., Theoretical foundations of chemical refining processes, [in Russian], KDU: Moscow, 2010. 